\title{
Entrepreneurial Readiness among Female Students: Does the Effectiveness of Time Management Matters in Attempting Businesses?
}

Noorkartina Mohamad, Nor Ermawati Hussain

To Link this Article: http://dx.doi.org/10.6007/IJARBSS/v11-i12/11821

DOI:10.6007/IJARBSS/v11-i12/11821

Received: 05 October 2021, Revised: 07 November 2021, Accepted: 30 November 2021

Published Online: 24 December 2021

In-Text Citation: (Mohamad \& Hussain, 2021)

To Cite this Article: Mohamad, N., \& Hussain, N. E. (2021). Entrepreneurial Readiness among Female Students: Does the Effectiveness of Time Management Matters in Attempting Businesses? International Journal of Academic Research in Business and Social Sciences, 11(12), 811-828.

Copyright: (c) 2021 The Author(s)

Published by Human Resource Management Academic Research Society (www.hrmars.com)

This article is published under the Creative Commons Attribution (CC BY 4.0) license. Anyone may reproduce, distribute, translate and create derivative works of this article (for both commercial and non0-commercial purposes), subject to full attribution to the original publication and authors. The full terms of this license may be seen at: http://creativecommons.org/licences/by/4.0/legalcode

Vol. 11, No. 12, 2021, Pg. 811 - 828

Full Terms \& Conditions of access and use can be found at http://hrmars.com/index.php/pages/detail/publication-ethics 


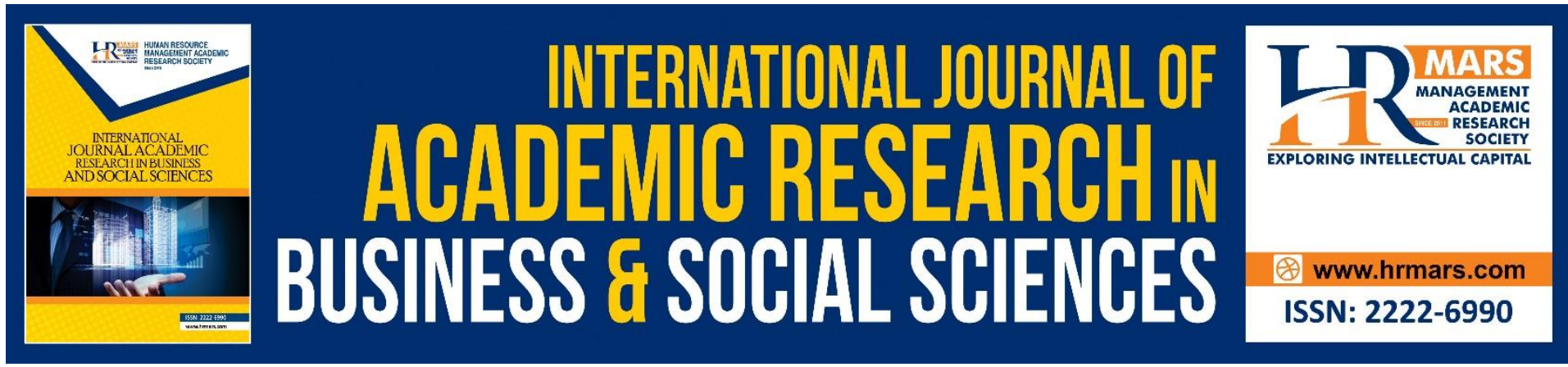

\title{
Entrepreneurial Readiness among Female Students: Does the Effectiveness of Time Management Matters in Attempting Businesses?
}

\author{
Noorkartina Mohamad \\ Faculty of Business and Science Management, Islamic College University Malaysia Perlis, \\ Perlis, Malaysia
}

\section{Nor Ermawati Hussain}

Faculty of Business, Economic and Social Development, Universiti Malaysia Terengganu,

Kuala Nerus, Terengganu, Malaysia.

Corresponding Author: kartina@kuips.edu.my

\begin{abstract}
The competition between businesses allusively opens up opportunities for entrepreneurs to continually find ways to enhance their product strategy in marketing and quality through innovation. However, for some students, venturing in entrepreneurship can help them receive extra income. Students nowadays are very keen to get involved in entrepreneurship while still studying. Simultaneously, some of them have been exposed to entrepreneurship since childhood. As the number of female students exceeds male students in higher education institutions, the purpose of this study is to determine the readiness of female students in entrepreneurship and time management effectiveness between learning and business. A cross-sectional survey was employed in this study, and data were collected from 386 female students in Malaysian Higher Education Institutions (response rate $=96.5 \%$ ). Using Regression Analysis, ANOVA and Data Envelopment Analysis (DEA), the study found that family support, business education, and entrepreneurship skills influence female students' readiness to become entrepreneurs. Besides, only 10.8 per cent of students have effectiveness in time management. To produce a successful female student as an entrepreneur, the government needs to provide motivation and psychological training to manage their time effectively. The balance between business and learning for these students is crucial and needs to emphasize by many parties. This is essential if Malaysia wants to produce highly educated female entrepreneurs.
\end{abstract}

Keywords: Entrepreneurship, Business Venturing, Readiness, Time Management, Effectiveness.

Introduction

Entrepreneurship is essential in today's world and becomes a catalyst for developing an economy of a nation. It is highly encouraged worldwide and was described in the literature as 
the process of human capital development through job creation (Brancu et al., 2012; Histrich \& Peter, 1986; McMillan \& Woodruff, 2002) by producing goods and services (Brancu et al., 2012; Histrich \& Peter, 1986; Zahra \& Dess, 2001) and taking risks from various perspectives, including financial, psychological, social, and economic benefits (Histrich \& Peter, 1986; Marniati, 2016). Entrepreneurship is a necessary part of the evolutionary process of any nation. However, entrepreneurship theory based on the economic approach has emphasized two main elements: profit and wealth. Both of these elements will motivate individuals to engage in entrepreneurial activities (Marshall, 2009). Referring to a study conducted by Nagarathanam and Buang (2015), business is one of the industries that has significantly contributed to economic growth. It is because entrepreneurs are individuals who are capable of managing an organization and are aware of the risks involved in the business (Mazzarol, 2011).

From an economic perspective, entrepreneurship contributes to the increase in income per capita and acts as a catalyst for social structural change. In the era of globalisation, entrepreneurship is considered one of the most crucial areas of economic growth. The development of entrepreneurship and the increase in the number of entrepreneurs contributed to the nation's positive economic development. Nowadays, entrepreneurship has supported the world economy's growth and become one of the dynamics in developing countries (Aaijaz et al., 2013; McMillan and Woodruff, 2002). Every entrepreneur will be looking at products that will be sold at the highest quality and guaranteed to provide positive results to the public (Peng \& Yan, 2010). Innovations through entrepreneurship will increase the supply of products in the market and creates diversity in a market economy (Ghani \& Sarif, 2005).

Entrepreneurship can be elucidated as a process of innovation and creation through four dimensions: i) individuals, ii) organizations, iii) the environment, and iv) processes in collaboration with networks within government, education, and institutions (Kuratko \& Hodgetts, 2004). In line with the Malaysian government's proposition, individuals should not only rely on jobs provided by the government and the private sector. Besides, the difficulty for graduating students from higher education institutions in obtaining jobs after graduation has prompted the government to encourage them to choose entrepreneurship as their leading career (Idris, 2009; McMillan \& Woodruff, 2002).

Based on Marniati (2016), an individual who wants to do business must have the capital and ability to manage it. It is because business success depends on knowledge and self-confidence in business management. Therefore, effective business management helps to ensure that entrepreneurs can survive on the business stage. As an industrialized nation, Malaysia is focusing on developing and training human capital in entrepreneurship, especially to university students (Norasmah \& Faridah, 2010). Some students have acquainted with entrepreneurship since childhood because some of their family members are entrepreneurs. Therefore, they are more likely to run a business while studying, especially in higher education institutions. Implementing education and entrepreneurial training in higher education institutions can help these students manage their business. Faoite et al (2003) said that education and entrepreneurship training provided to students concentrate on improving the quality of business, the number of young entrepreneurs and the catalyst for national economic development. The support from the government through the implementation of 
some policies, training, and assistance for students to become entrepreneurs is important. Even after they have graduated, they can still participate in the training with a specific procedure.

Through the policies implemented by the government, it can attract more students and graduates of higher education institutions to engage in entrepreneurship (You et al., 2017). However, there are differences in business management interests and attitudes between male and female entrepreneurs (Lo et al., 2012). Therefore, this study is more focused on female student readiness to become entrepreneurs. In Malaysian higher education institutions, the number of female students is higher than male students. As a result, this study's objectives are to determine the readiness of female students in entrepreneurship and to examine the time management effectiveness of entrepreneur students between business education and learning.

One of the motives that make females choose a career as entrepreneurs is to increase their family income (Mahashim, 1985) and interest the business (Lo et al., 2012). Although entrepreneurship is a high-risk area for failure, females' involvement in entrepreneurship tends to yield positive outcomes. Therefore, special attention should be given to female entrepreneurs, including female student entrepreneurs, to understand the key factors that can help them continue to be involved in entrepreneurship (Yulita et al., 2020). Referring to a study conducted by Norain (2015), female entrepreneurs are increasingly using social media as a medium for business through online business. Additionally, this can save female entrepreneurs time in business management and help solve females' dilemmas in balancing work and daily life.

\section{The Entrepreneurial Readiness Among Female Students Entrepreneurial Readiness}

Based on Rengamani and Ramachandran (2015), the trend of youth participation in entrepreneurship has increased over time. This is because some factors have influenced the younger generation's readiness to enter into entrepreneurship, especially the students. China, Li and $\mathrm{Wu}$ (2017) found that the number of siblings influenced their decision to become entrepreneurs. A large number of siblings will cause money problems, and the best solution is to do entrepreneurial activities. In contrast to Li and Wu (2017), Lindquist et al. (2016) stated that many siblings did not influence the decision to become an entrepreneur in Denmark. However, several factors contribute to the success of an entrepreneur; such as selfconfidence (Ayub et al., 2017) and creativity in managing the business (Tong et al., 2011). For Ayub et al. (2017), the factor of self-confidence is essential for individuals engaged in entrepreneurship. Self-confidence refers to external and internal self-control through confidence in the ability to manage a business. Meanwhile, Tong et al. (2011) said that entrepreneurs need to have a creative idea when operating a business through an innovation process. It is an important key to encourage young people to get involved in entrepreneurship. Pursuing a career as an entrepreneur is risky, but it can contribute to economic growth. Thus, higher education institutions are some of the best places to realize this young generation's dream. Refer to Barba-Sanchez and Atienza-Sahuquillo (2018), one of the universities' goals nowadays is to encourage students towards entrepreneurship by providing various training and education programs related to business/entrepreneurship. 


\section{Family Support}

Family support has been considered to be important in venturing a business. Parents involved in entrepreneurship will influence their children to become entrepreneurs (Lindquist et al., 2016). Usually, individuals become entrepreneurs due to several factors, including family support. Family support includes financial support (Au et al., 2016; Edelman et al., 2016), emotion, knowledge (Au et al., 2016), and social support (Edelman et al., 2016). Students who wish to venture into a business require financial capital. Therefore, the family usually provides financial assistance to these students who desire to become entrepreneurs (Au et al., 2016). Referring to Shen et al (2016), an entrepreneurial family leader can help their family members who want to open a new business through knowledge sharing and business advice. In addition to the sharing of knowledge to shape entrepreneurship behaviour, Sorensen (2007) argues that family members can also give moral support to young entrepreneurs, especially those students who want to start a business. Some studies associated students' entrepreneurship with a family background (Aaijaz et al., 2013; Amentie \& Negash, 2014; Brancu et al., 2012; Shen et al., 2017). Shen et al (2017) found that family support was positively related to students' aspiration to become entrepreneurs in the United States. Simultaneously in Malaysia, Aaijaz et al. (2013) found that mothers' work as entrepreneurs did not influence female students to become entrepreneurs. Instead, the participation of female students in entrepreneurship received moral support from family members. Like Aaijaz et al (2013), in Ethopia, Amentie and Negash (2014) found that female students receive moral support from family members to become entrepreneurs.

\section{Business Education}

Education related to business and entrepreneurship needs to be applied to the students to open up opportunities for new entrepreneurs and create employment opportunities in nations (Hassi, 2016; Brancu et al., 2012). A study conducted by Tawil et al. (2015), who studied entrepreneurship courses, has successfully stimulated students' interest to venture into entrepreneurship. The exposure provided through the entrepreneurial model has given students confidence in their ability to start a business (Boldureanu et al., 2020). There are several studies related to business/entrepreneurial education that has been done by researchers in prior studies (Brancu et al., 2012; Lo et al., 2012; Mustafa, 2019; Norasmah \& Faridah, 2010; You et al., 2017). Brancu et al (2012) found that the difference in sociodemographic profile and education level has influenced students to become entrepreneurs. This is because entrepreneurship can create various job opportunities. Furthermore, Lo et al. (2012) found differences in terms of the interest to become an entrepreneur between males and females students. Males students are more interested in becoming entrepreneurs if they have a lot of business knowledge. But for female students, they become entrepreneurs regardless of educational background in entrepreneurship. Meanwhile, You et al (2017); Norasmah and Faridah (2010); Mustafa (2019) conducted a study on university students' knowledge and their interest in entrepreneurship. In China, You et al (2017) found that college graduates have higher entrepreneurial goals than university graduates. Nonetheless, the university entrepreneurial guidance and training are given to students more than those at colleges. Similarly, Norasmah and Faridah (2010) found that university students in Malaysia have higher entrepreneurial knowledge than others. Refer to Mustafa (2019), university students are highly knowledgeable about entrepreneurship, and they have been exposed to entrepreneurship during their studies. The support and stimulus provided by the university have helped students to get involved in entrepreneurship. 


\section{Entrepreneurship Skills}

Entrepreneurial skills are essential to entrepreneurs. Lichtenstein and Lyons (2001) argued that every problem faced by an entrepreneur is different, so existing skills can help save the entrepreneur's business. Similarly, Omolara (2018) stated that skilled entrepreneurs could solve many of the complexities that may affect their business growth. Among the business skills that entrepreneurs need to apply are communication and problem-solving skills (Lind, 2005). The skills of entrepreneurs need to be developed over time so that they can be improved. Indirectly, these skills can help entrepreneurs succeed in running the business (Lyons et al., 2019). Thus, for students who wish to become entrepreneurs, entrepreneurial skills need to be applied to them from time to time. Beranek (2014) said that entrepreneurial skills are already being used in student entrepreneurship, but there is still a lack of motivation to help students in business competitions. In Malaysia, Ibrahim and Dawood (2020) stated that the interest in entrepreneurship comes from a family background inherited and developed from time to time. On the contrary, refer to Mustapha et al (2017), the value of entrepreneurship depends on the individual's experience and knowledge, not the influence from family background, and such relationships cannot be inherited. In another study conducted by Pauceanu et al (2019), it was found that the tendency of students at the UAE University to become entrepreneurs is due to self-confidence before starting a business. Therefore, based on the previous studies above, the hypotheses of the study are proposed as follows (see Figure 1):

Hypothesis 1: Family support is the main factor in the readiness of female students to become entrepreneurs.

Hypothesis 2: Business education mediates the relationship between family support and entrepreneurial readiness among female students.

Hypothesis 3: Entrepreneurship skills moderate the relationship between business education and entrepreneurial readiness.

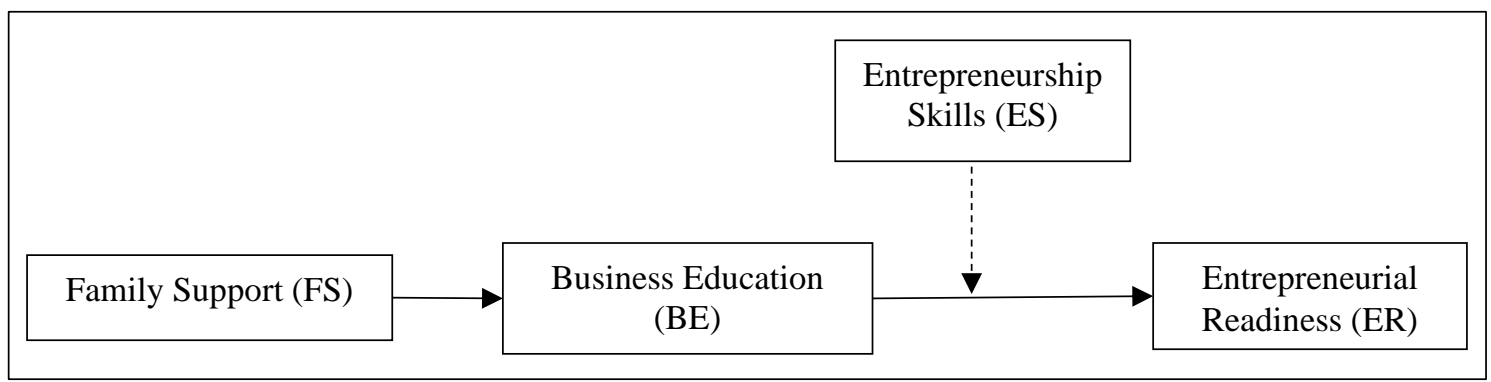

Figure 1. Research Framework (Entrepreneurial Readiness)

\section{The Time Management Effectiveness}

Time management has been regarded as a key skill for achieving desired goals. The effectiveness of time management also influences the success of an entrepreneur. Referring to Aeon and Aguinis (2017), effective time management can increase individual performance because effective time management does not occur naturally, but it should be planned carefully (Steven, 2009). Lassier (2008) defined time management as a technique that requires planning to accomplish a task with minimal time, and the results are excellent. For Sunday et al. (2019), entrepreneurs can seize the available opportunities through a strategy that is planned earlier. Effective time management aims to create a good time layout and increase the productivity of work being done by an individual (Claessens et al., 2007; Lassier, 
2008). Good time management can help entrepreneurs overcome stress in their lives (Adebisi, 2013; Ahmad et al., 2012; Rengamani \& Ramanchandran, 2015). Ongoing studies are looking at time management among students who wish to become entrepreneurs. Based on the study conducted by Zarbakhsh et al. (2015), there is a positive correlation between time management and time to learn and do business. Hence, time management is emphasized in student entrepreneurship to allocate time for business and learning better. Based on this discussion, the following hypothesis is developed:

Hypothesis 4: Entrepreneurial readiness and business education encourage female students to manage their business effectively.

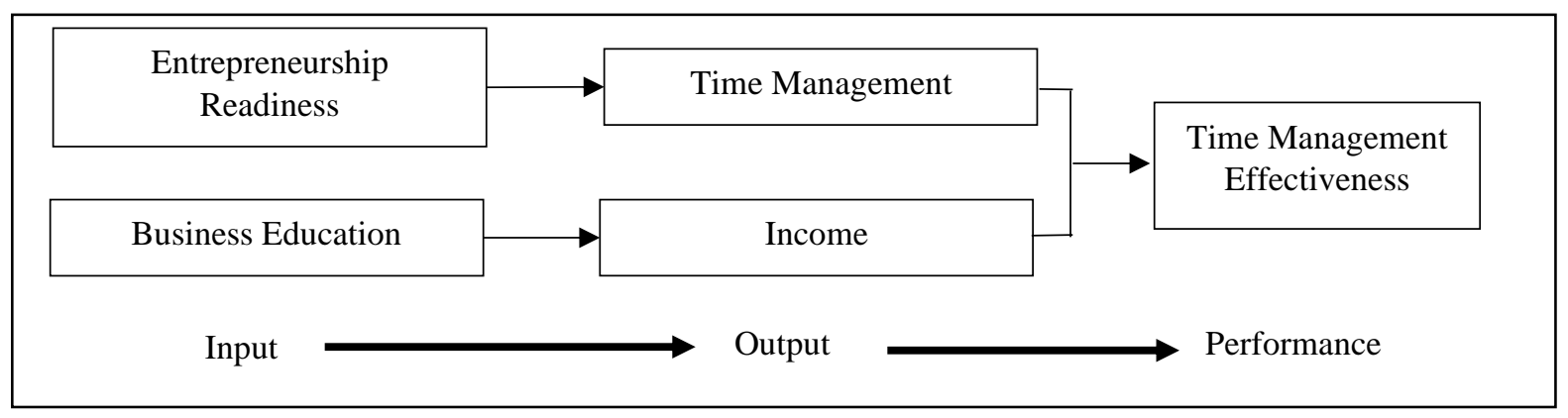

Figure 2. Research Framework (Time Management Effectiveness)

\section{Methodology}

\section{a. Research Procedure/Settings}

The study focuses on female student entrepreneurs studying at Institutions of Higher Learning in Malaysia. Thus, the sample size classification based on the population sampling method introduced by Krejcie and Morgan in 1970. A total of 400 female student entrepreneurs were randomly selected, but only 386 students answered the questionnaires. The questionnaire was designed based on a previous study by Zolkefli et al. (2019), Bahari (2019), and Amentie $\&$ Negash (2014). Open-ended questions were obtained to receive respondents' demographic information. Simultaneously, the questionnaire using the Likert scale intended to identify other elements such as business education, entrepreneurship skills, entrepreneurial readiness, family support and time management (1=strongly disagree, $2=$ disagree, $3=$ uncertain, 4=agree, $5=$ strongly agree).

In this study, age and number of siblings were used as control variables. This study can spot at the age at which the highest number of students tend to be entrepreneurs. Besides, these female students' decision to continue their entrepreneurship is also influenced by the siblings' number. The factors loading for the reliability of these variables ranged from 0.758 to 0.859 . Regression analysis and ANOVA were performed using Statistical Package for the Social Sciences (SPSS) to answer objective 1 (Hypothesis 1, Hypothesis 2, and Hypothesis 3). In contrast, Data Envelopment Analysis (DEA) is used to answer objective 2 (hypothesis 4). Therefore, Table 1 shows the types of models that will be used in this study to answer Hypothesis 1, Hypothesis 2, and Hypothesis 3. 
Table 1. Types of Model (Dependent Variable: Entrepreneurial Readiness)

\begin{tabular}{ll}
\hline \multicolumn{1}{c}{ Model Types } & \multicolumn{1}{c}{ Variables } \\
\hline Model 1 (CV) & Age; Number of Siblings. \\
Model 2 (CV, ME) & Age; Number of Siblings; Business Education. \\
Model 3 (CV, ME, MO) & Age; Number of Siblings; Business Education; Entrepreneurship \\
& Skills. \\
Model 4 (CV, MV, MO, & Age; Number of Siblings; Business Education; Entrepreneurship \\
ME) & Skills; Family support. \\
Model 5 (CV, MV, MO, & Age; Number of Siblings; Business Education; Entrepreneurship \\
ME, IE) & Skills; Family support; Family Support + Business Education; \\
& Family Support + Business Education + Entrepreneurship Skills. \\
\hline
\end{tabular}

$C V=$ Control Variables, $M V=$ Mediating Variables, $M O=$ Moderating Variables, $M E=$ Main Effect, IE = Interaction Effect.

According to the demographic survey, most entrepreneurial students are between the ages of 22 to 24 (77\%), and $98 \%$ are Malays. 99\% of these student entrepreneurs are undergraduate students. $65 \%$ of these students are from less developed states in Malaysia, while $35 \%$ of entrepreneurial students are from developed states. At the same point, $73 \%$ of these students do online business, while the rest do the franchise (2\%), services (21\%), and booths/kiosks (4\%). The majority of them earn between RM0-RM600 a month (93\%). When looking at the family background, $58 \%$ of students have 4 to 6 siblings, while $20 \%$ of students have between 0 and 3 siblings, and $22 \%$ have more than seven siblings. Meanwhile, $84 \%$ say their parents are not entrepreneurs for the parent job, only $16 \%$ say that at least one of their parents is an entrepreneur.

\section{b. Entrepreneurial Readiness}

The selection of entrepreneurial readiness as a dependent variable follows hypotheses 1,2 , and 3 , seeing the relationship between independent variables (business education, entrepreneurship skills, and family Support) with entrepreneurial readiness. Entrepreneurial readiness refers to female students' interest to become entrepreneurs while studying at Institutions of Higher Education. The reliability value of this entrepreneurial readiness is $\alpha=$ 0.859. A few questions asked to the respondents regarding this entrepreneurial readiness were 'I have an entrepreneurship plan when starting a business', 'I have a talent for running a business', and 'I like a job in entrepreneurship'.

\section{c. Business Education}

As a mediator, business education is seen as being influenced by family support and can affect female students' entrepreneurial readiness. Business education refers to knowledge that has been followed by this student related to entrepreneurship and business. Thus, the reliability of business education is $\alpha=0.781$. The questions posed to the respondents about business education were 'my degree in business/entrepreneurship', 'I take subject entrepreneurship in university', and 'degree studies at university influenced me to become an entrepreneur'.

\section{d. Student Entrepreneur}

With skills, a student entrepreneur can become a successful entrepreneur. So, entrepreneurship skills serve as a mediator is to see how far the existing skills of entrepreneur students will affect entrepreneurial readiness. Entrepreneurship skills refer to skills related to 
entrepreneurship adopted by the current student entrepreneurs doing business. Therefore, the reliability value for entrepreneurship skills is $\alpha=0.815$. Some of the questions asked about entrepreneurship skills are 'I have business skills', and 'I apply the subject of entrepreneurship to business activity'.

\section{e. Family Support}

The tendency of student entrepreneurs is due to family support. Therefore, this study makes family support the main effect because entrepreneurial readiness among female students is due to family. Family Support refers to the encouragement given by these student entrepreneurs' family members to pursue their business has grown. Thus, the reliability of family support is $\alpha=0758$. Some of the questions raised regarding family support are 'Family supports me to become an entrepreneur', and 'Family members are mentors/advisors when I started a business'.

\section{f. Efficiency Analysis}

Next, efficiency analysis tests to see the effectiveness level of entrepreneur students in entrepreneurship. This test uses an input-output approach, where entrepreneurial readiness and business education are inputs, while time management and income are outputs (Table 2). Among the questions raised in time management is 'Doing business, time management becomes more regular,' and 'I know how to divide the time between learning by doing business'. The range for this efficiency analysis is between 0 and 1. If the value is closer to 1 , the time management of entrepreneur students is effective. However, if the value obtained is close to 0 , entrepreneur students' time management is not effective.

Table 2. Input-Output

\begin{tabular}{cc}
\hline Input & Output \\
\hline $\begin{array}{c}\text { Entrepreneurial Readiness } \\
\text { Business Education }\end{array}$ & Time Management \\
\hline
\end{tabular}

\section{Results and Discussion}

Table 3 shows descriptive statistical results, namely mean (M), standard deviation (DV), and the correlation between variables. There were correlations between variables except for the correlation between the number of siblings and the respondent's age and the correlation between family support and respondent's age. Subsequently, Table 4 and Table 5 show the regression tests results by group and individual (through Anova test and regression test). Based on the Anova test results (Table 4), all models (model 1 to model 5) were significant at the $1 \%$ significance level, and this indicated that there was a relationship between the variables as a group (refer to F-statistic).

Additionally, according to Table 5, the results show that the relationship between entrepreneurial readiness and other variables; it was significant for all models at the $0.1 \%$, $1 \%$, and $5 \%$ significance level [except Model 5 was insignificant for the interaction effect of 3 variables (family support*business education*entrepreneurship skills)]. Based on Model 1 to model 5 (control variables only), age is positively associated with entrepreneurial readiness, while the number of siblings has a negative relationship with entrepreneurial readiness. Business education was positively associated with entrepreneurial readiness (Model 2 to Model 4), whereas business education was negatively related to entrepreneurial readiness in 
Model 5 (significant at the $5 \%$ level). Next, the moderating variable (Model 3 and Model 5 ) found that entrepreneurship skills have a positive relationship with entrepreneurial readiness. For the main effect, the study found that family support has a positive relationship with the entrepreneurial readiness in Model 4 and has a negative association with the entrepreneurial readiness in Model 5. And for the interaction effect (Model 5), the study found that family support*business education has a positive relationship with entrepreneurial readiness. However, Model 5 also found no significant interaction effect between family support*business education*entrepreneurship skills.

Table 3. Descriptive Statistic and Correlations

\begin{tabular}{lccccccc}
\hline \multicolumn{1}{c}{ Variables } & M & SD & $\mathbf{1}$ & $\mathbf{2}$ & $\mathbf{3}$ & $\mathbf{4}$ & $\mathbf{5}$ \\
\hline 1 Age & 22.3 & 1.032 & & & & & \\
& 1 & & & & & & \\
2 Number of Siblings & 5.18 & 2.175 & 0.044 & & & & \\
3 Entrepreneurial & 3.77 & 0.746 & $0.211^{*}$ & - & & & \\
$\quad$ Readiness & 9 & & $*$ & $0.127^{*}$ & & & \\
& & & & $*$ & & & \\
4 Family Support & 3.46 & 0.874 & 0.026 & $0.139 *$ & $0.258^{*}$ & & \\
& 0 & & & $*$ & $*$ & & \\
5 Business Education & 3.46 & 1.094 & $0.203^{*}$ & -0. & $0.492^{*}$ & $0.212^{*}$ & \\
& 1 & & $*$ & $097^{*}$ & $*$ & $*$ & \\
6 Entrepreneurship & 4.19 & 0.522 & $0.182^{*}$ & $0.139 *$ & $0.425^{*}$ & $0.248^{*}$ & $0.384^{*}$ \\
$\quad$ Skills & 5 & & $*$ & $*$ & $*$ & $*$ & $*$ \\
\hline
\end{tabular}

Note: ${ }^{* *} p<0.01$ and $* p<0.05$ significance levels of two-tailed. 
INTERNATIONAL JOURNAL OF ACADEMIC RESEARCH IN BUSINESS AND SOCIAL SCIENCES Vol. 11, No. 12, 2021, E-ISSN: 2222-6990 @ 2021 HRMARS

Table 4. Readiness for Becoming Entrepreneurship (Anova Test)

\begin{tabular}{|c|c|c|c|c|c|}
\hline ANOVA Test & $\begin{array}{c}\text { Sum of } \\
\text { Squares }\end{array}$ & df & Mean Square & $\mathbf{F}$ & Prob. \\
\hline \multicolumn{6}{|l|}{ Model 1} \\
\hline & $13.583 * * *$ & $2 * * *$ & $6.791^{* * *}$ & $12.968 * * *$ & $0.000 * * *$ \\
\hline \multicolumn{6}{|l|}{ Regression*** } \\
\hline Residual & 200.572 & 383 & 0.524 & & \\
\hline Total & 214.154 & 385 & & & \\
\hline \multicolumn{6}{|l|}{ Model 2} \\
\hline & $50.524 * * *$ & $3 * * *$ & $16.841^{* * *}$ & $39.317^{* * *}$ & $0.000 * * *$ \\
\hline \multicolumn{6}{|l|}{ Regression*** } \\
\hline Residual & 163.630 & 382 & 0.428 & & \\
\hline Total & 214.154 & 385 & & & \\
\hline \multicolumn{6}{|l|}{ Model 3} \\
\hline & $71.359 * * *$ & $4 * * *$ & $17.840 * * *$ & $47.599 * * *$ & $0.000 * * *$ \\
\hline \multicolumn{6}{|l|}{ Regression*** } \\
\hline Residual & 142.796 & 381 & 0.375 & & \\
\hline Total & 214.154 & 385 & & & \\
\hline \multicolumn{6}{|l|}{ Model 4} \\
\hline & $75.228 * * *$ & $5 * * *$ & $15.046 * * *$ & $41.153^{* * *}$ & $0.000 * * *$ \\
\hline \multicolumn{6}{|l|}{ Regression*** } \\
\hline Residual & 138.927 & 380 & 0.366 & & \\
\hline Total & 214.154 & 385 & & & \\
\hline \multicolumn{6}{|l|}{ Model 5} \\
\hline & $82.733^{* * *}$ & $7 * * *$ & $11.819 * * *$ & $33.994 * * *$ & $0.000 * * *$ \\
\hline \multicolumn{6}{|l|}{ Regression*** } \\
\hline Residual & 131.422 & 378 & 0.348 & & \\
\hline Total & 214.154 & 385 & & & \\
\hline
\end{tabular}


Table 5. Regression and Interaction Effects on Entrepreneurial Readiness among Female Students

\begin{tabular}{|c|c|c|c|c|c|}
\hline Variables & Model 1 & Model 2 & Model 3 & Model 4 & Model 5 \\
\hline Constant & $\begin{array}{c}0.466 \\
(2.396)^{* *}\end{array}$ & $\begin{array}{c}0.363 \\
(2.358)^{* *}\end{array}$ & $\begin{array}{c}0.208 \\
(2.655)^{* *}\end{array}$ & $\begin{array}{c}0.143 \\
(2.362)^{*}\end{array}$ & $\begin{array}{c}0.065 \\
(1.972)^{*}\end{array}$ \\
\hline \multicolumn{6}{|l|}{ Control Variables } \\
\hline Age & $\begin{array}{c}0.157 \\
(4.358)^{* * *}\end{array}$ & $\begin{array}{c}0.103 \\
(3.126)^{* *}\end{array}$ & $\begin{array}{c}0.068 \\
(2.174)^{*}\end{array}$ & $\begin{array}{c}0.072 \\
(2.349)^{*}\end{array}$ & $\begin{array}{c}0.082 \\
(2.709)^{* *}\end{array}$ \\
\hline $\begin{array}{l}\text { Number of } \\
\text { Siblings }\end{array}$ & $\begin{array}{c}-0.047 \\
(2.767)^{* *}\end{array}$ & $\begin{array}{c}-0.066 \\
(-4.270)^{* * *}\end{array}$ & $\begin{array}{c}-0.048 \\
(-3.236)^{* * *}\end{array}$ & $\begin{array}{c}-0.054 \\
(-3.685)^{* * *}\end{array}$ & $\begin{array}{c}-0.039 \\
(-2.582)^{* *}\end{array}$ \\
\hline \multicolumn{6}{|l|}{ Mediator } \\
\hline $\begin{array}{l}\text { Business } \\
\text { Education }\end{array}$ & - & $\begin{array}{c}0.609 \\
(9.287)^{* * *}\end{array}$ & $\begin{array}{c}0.421 \\
(6.343)^{* * *}\end{array}$ & $\begin{array}{c}0.386 \\
(5.807)^{* * *}\end{array}$ & $\begin{array}{c}-0.382 \\
(2.347)^{*}\end{array}$ \\
\hline \multicolumn{6}{|l|}{ Moderator } \\
\hline $\begin{array}{l}\text { Entrepreneurship } \\
\text { Skills } \\
\text { Main Effect }\end{array}$ & - & - & $\begin{array}{c}0.236 \\
(7.456)^{* * *}\end{array}$ & $\begin{array}{c}0.220 \\
(6.948)^{* * *}\end{array}$ & $\begin{array}{c}0.308 \\
(2.534)^{* *}\end{array}$ \\
\hline Family Support & - & - & - & $\begin{array}{c}0.121 \\
(3.253)^{* *}\end{array}$ & $\begin{array}{c}-0.371 \\
(-3.211)^{* * *}\end{array}$ \\
\hline \multicolumn{6}{|l|}{ Interaction Effect } \\
\hline $\mathrm{FS} * \mathrm{BE}$ & - & - & - & - & $\begin{array}{c}0.166 \\
(2.300)^{*}\end{array}$ \\
\hline $\mathrm{FS}^{*} \mathrm{BE} * \mathrm{ES}$ & - & - & - & - & $\begin{array}{c}-0.004 \\
(-0.279)\end{array}$ \\
\hline \multicolumn{6}{|l|}{ Model Fit } \\
\hline $\mathrm{R}^{2}$ & 0.063 & 0.236 & 0.333 & 0.351 & 0.386 \\
\hline$\Delta \mathrm{R}^{2}$ & 0.059 & 0.230 & 0.326 & 0.343 & 0.375 \\
\hline
\end{tabular}

Notes: Dependent variables is Entrepreneurial Readiness; ( ) refers to t-statistics value; $* * * p<0.001, * * p<0.01$ and $* p<0.05$ significance levels of two-tailed, while $n=386$.

Furthermore, Table 6 shows the results to see the effectiveness of time management. The results show that only $1 \%$ of students have full effectiveness ( $100 \%$ effectiveness) in time management (between learning and business), and $9.8 \%$ of students achieve effectiveness between $80 \%$ - 99.9\%. Meanwhile, most student entrepreneurs $(62.1 \%)$ were in the moderate between $50 \%-79.9 \%$ and $27.1 \%$ of the student entrepreneurs were less effective (less than $50 \%$ effectiveness). It extrapolates that the majority of students are not yet effective in managing time between studying and business. 
Table 6. Time Management Effectiveness when Jumped into Business

\begin{tabular}{|c|c|c|c|c|c|c|c|c|c|}
\hline \multirow{3}{*}{$\begin{array}{c}\text { Rate of } \\
\text { Effectiveness }\end{array}$} & \multicolumn{7}{|c|}{ Aged (years old) } & \multirow{3}{*}{$\begin{array}{c}\text { Respondents } \\
\text { Percentage } \\
\text { (\%) }\end{array}$} & \multirow[t]{3}{*}{ Effectiveness (/) } \\
\hline & 2 & 21 & 22 & 23 & 24 & 2 & 2 & & \\
\hline & 0 & & & & & 5 & 6 & & \\
\hline 100 & - & - & 4 & - & - & - & - & 1.0 & $\begin{array}{c}\text { (/) Full } \\
\text { Effectiveness }\end{array}$ \\
\hline $80-99.9$ & - & 8 & 22 & 4 & 4 & - & - & 9.8 & $\begin{array}{c}\text { (/) } \\
\text { Effectiveness }\end{array}$ \\
\hline $50-79.9$ & 4 & 42 & 104 & 66 & 12 & 8 & 4 & 62.1 & Moderates \\
\hline$<50$ & 4 & 14 & 42 & 32 & 12 & - & - & 27.1 & $\begin{array}{c}\text { Less } \\
\text { Effectiveness }\end{array}$ \\
\hline Total $(n=386)$ & 8 & 64 & 172 & $\begin{array}{c}10 \\
2\end{array}$ & 28 & 8 & 4 & 100 & \\
\hline
\end{tabular}

Based on the regression test results (Table 5), entrepreneurial readiness has a positive relationship with family support (Model 4). It indicates that family support is a crucial driver of the student to become entrepreneurs. Therefore, hypothesis 1 states that family support is the main factor in female students' readiness to become entrepreneurs. This result is similar to the study conducted by Aaijaz et al. (2013) in Malaysia and Amentie and Negash (2014) in Ethiopia. Encouragement and family support to allow female student entrepreneurs to survive in the stage entrepreneurs are essential. Family support is not just in the form of money but also in energy and moral support.

Furthermore, as seen in Model 5, family support has a negative and significant relationship with entrepreneurial readiness. But based on the interaction effect, the combination of family support*business education appears to have a positive and significant relationship with entrepreneurial readiness. It shows that the continuity between family support and business education has made students more inclined to become entrepreneurs than just family support. Thus, hypothesis 2 states that business education mediates within family support, and entrepreneurial readiness among female students is accepted. Some of these students have been exposed to entrepreneurship since childhood, so their passion for entrepreneurship has grown. After graduating from school and pursuing tertiary education, these students tend to choose the field of study that suits their interests. The exposure they received while studying at the university encouraged them to continue doing business. Female entrepreneurs are seen as capable of success in the business world if given a great deal of exposure to entrepreneurship, especially at university. These successes will encourage other students to pursue entrepreneurship.

According to Hypothesis 3, entrepreneurial skills moderate business education on entrepreneurial readiness, which is rejected. For Model 5, the effect of interaction between family support*business education*business skills was found to be unrelated to entrepreneurial readiness and not significant. At university, student entrepreneurs lack the training and skills related to business/entrepreneurship. Only business and entrepreneurship education is provided at the university level. Therefore, the emphasis on business skills among student entrepreneurs is important for many parties to consider if they want to see them continue to thrive in entrepreneurship even after graduation. 
Additionally, according to Table 6 , the results show that only $10.8 \%$ of student entrepreneurs are efficient in managing time between studying and business. The majority of student entrepreneurs cannot manage their time well, and if this continues, it will disrupt the learning of the students. Therefore, based on hypothesis 4, entrepreneurial readiness and business education encourage female students to manage their business effectively, it is rejected. Supposedly related courses and training effective time management should be given to the students to manage their time to learn the business effectively.

\section{Conclusion}

In conclusion, the research objectives and all the hypotheses have been answered. Hypothesis 1 , hypothesis 2 , and hypothesis 3 are based on objective 1 , which is to determine female students' readiness in entrepreneurship. The results showed that hypothesis 1 and hypothesis 2 were accepted, while hypothesis 3 was rejected. It shows that student entrepreneurs are willing to be entrepreneurs, but there is a lack of entrepreneurship skills. Thus, exposure to entrepreneurial skills should be given to the students. It is because the entrepreneurship skills obtain will help them to continue successfully in the future. Next, Hypothesis 4 based on objective 2, which examines the time management effectiveness of entrepreneur students between business and learning. The results showed that hypothesis 4 also rejected. It indicates that female student entrepreneurs cannot manage their time between business and learn well.

To ensure the successful female entrepreneurs in the future, internal motivation and skills training must be given to them. Referring to Marniati (2016) and Mustafa (2019), motivation is important for entrepreneurial students as it can motivate them to move further into the challenging entrepreneurial world. Therefore, various parties, including the university and the ministry, should provide a variety of training and motivation to help young entrepreneurs advance in the world of entrepreneurship. First, the motivation must be instilled in the student entrepreneurs. It is because students need to be exposed to the challenges they will face. Therefore, an essential element of motivation is to encourage students to be prepared for the challenges they face in the real world of entrepreneurship. Furthermore, psychology training is also necessary to ensure that students can control and communicate well with their customers. Even in psychology training, student entrepreneurs will also be trained to handle emotions in anything untoward in their business. There are studies related to psychology conducted by Leung et al. (2020) found an indirect relationship between psychiatric symptoms and entrepreneurship among student entrepreneurs at Dutch University.

To produce a successful female student as an entrepreneur, the government needs to provide motivation and psychological training to manage their time effectively. The balance between business and learning for these students is crucial and needs to emphasize by many parties. It is essential if Malaysia wants to produce highly educated female entrepreneurs. Thus, there are several plans for future studies, i) focusing on elements of motivation and psychology training, and ii) comparing entrepreneurial readiness between male and female students. The motivation and psychology elements of student entrepreneurs need to be known. If both elements are still weak for entrepreneur students, then the best solution will be to ensure that both elements can be applied to the student entrepreneurship. 


\section{g. Practical Implication}

Based on the findings, there is a problem with the mediator. In terms of interaction effects between the main effect (family support), mediating (business education) and mediator (entrepreneurship skills), the result was not significant. The result was a significant and positive relationship for the interaction effect between family support and business education. Therefore, the theory needs to be improved by incorporating several mediating, such as motivation and psychology training.

\section{h. Limitations and Future Research}

There are several limitations identified in this current study. One of the major limitations of this study and self-reported measures prone to common method bias or common method bias is inaccuracy (Podsakoff et al., 2003; 2012). However, several steps have been taken to overcome this problem, such as using control variables, age, and siblings. Regardless of this, future research can be improved by using repeated measures or longitudinally. Objective measurement can also be utilized to obtain more accurate findings. Another limitation is concerning the sample selection. This current study is limited to only bachelor degree students. Future research should employ more various levels of students sample (e.g., diplomas, masters, PhD, etc.) to improve its generalizability. Nonetheless, this present still contributes to the current literature. It is in line with previous empirical findings (Ayub et al., 2017; Barba-Sanchez \& Atienza-Sahuquillo, 2018), suggesting that this study is reliable.

\section{References}

Aaijaz, N., \& Ibrahim, M. D. (2013). Are Women Students more Inclined Towards Entrepreneurship? An Entrepreneurial University Experience. Journal on Business Review. 2 (3), 90-103.

Adebisi, J. F. (2013). Time Management Practices and Its Effect on Business Performance. Canadian Social Science. Vol. 9 (1), 165-168.

Aeon, B., \& Aguinis, H. (2017). It's About Time: New Perspectives and Insight on Time Management. Academy of Management Perspectives. Vol. 31 (4), 309-330.

Ahmad, N. L., Yusof, A. N. M., Shobri, N. D. M., \& Wahab, S. (2012). The Relationship between Time Management and Job Performance in Event Management. ProcediaSocial and Behavioral Sciences 65, 937-941.

Amentie, C., \& Negash, E. (2014). The Study on Female Undergraduates' Attitudes toward and Perceptions of Entrepreneurship Development (Comparison Public and Private Universities in Ethiopia). International Journal of Scientific and Research Publications. 4 (12), 1-17.

Au, K., Chian, F. F. T., Birtch, T. A., \& Kwan, H. K. (2016). Entrepreneurial Financing in New Business Ventures: A Help-Seeking Behavior Perspective. International Entrepreneurship and Management Journal. Vol. 12 (1), 199-213.

Ayub, M. S., Nasip, S., Fabeil, N. F., Buncha, M. R., Alias, H. N., \& Rahim, I. H. A. (2017). Entrepreneurial Intention among Students: A Study in Bulungan Tarakan, Indonesia. Proceedings of International Conference on Economic, 345-356.

Bahari, I. F. S. (2019). Faktor yang Mempengaruhi Mahasiswa di UMT dalam Menceburi Bidang Keusahawanan. Universiti Malaysia Terengganu; Terengganu.

Barba-Sanchez, V., \& Atienza-Sahuquillo, C. (2018). Entrepreneurial Intention among Engineering Students: The Role of Entrepreneurship Education. European Research on Management and Business Economics. Vol. 24, 53-61. 
Beranek, L. (2014). The Attitude of the College Students to Entrepreneurial Skill Development in the Subject E-commerce. Informatics in Education. Vol. 14 (1), 1-12.

Brancu, L., Munteanu, V., \& Gligor, D. (2012). Study on Student's Motivations for Entrepreneurship in Romania. Procedia-Social and Behavioral Sciences 62. 223-231.

Boldureanu, G., Ionescu, A. M., Bercu, A., Bedrule-Grigoruta, M. V., \& Boldureanu, D. (2020). Entrepreneurship Education through Successful Entrepreneurial Models in Higher Education Institutions. Sustainability. Vol. 12. 1-33.

Claessens, Brigitte, J. C., Eerde, W. V., Rutte, C. G., \& Roe, R. A. (2007). A Review of the Time Management Literature. Emerald Personel Review. Vol. 36 (2), 255-276.

Edelman, L. F., Manolova, T., Shirokova, G., \& Tsukanova, T. (2016). The Impact of Family Support on young Entrepreneurs. Journal of Business Venturing. Vol. 31, 428- 448.

Faoite, D. F., Henry, C., Johnson, K., \& Sijde, P. V. D. (2003). Education and Training for Entrepreneurs: A Consideration of Initiatives in Ireland and Netherlands. Education and Training. 45(8/9). 430-439.

Ghani, A. A. M., \& Sarif, S. (2005). Penerapan Budaya Keusahawanan dalam Masyarakat Islam. Seminar Keusahawanan Islam Peringkat Kebangsan 2005.

Hassi, A. (2016). Effectiveness of Early Entrepreneurship Education at the Primary School Level: Evidence from a Field Research in Morocco. Citizenship Social \& Economics Education. Vol. 15 (2), 83-103

Ibrahim, N., \& Dawood, S. R. S. (2020). Keunikan. Budaya Berniaga Wanita Kelantan di Bandar Kota Bharu. Journal of Social Sciences and Humanities. 17 (1), 93-107.

Idris, S. H. M. (2009). Kecenderungan Keusahawanan di Kalangan Pelajar Bidang Kejuruteraan di Institusi Pengajian Tinggi Awam di Kawasan Utara Semenanjung Malaysia. Sintok, Kedah; Universiti Utara Malaysia.

Kuratko, D. F., \& Hodgetts, R. M. (2004). Entrepreneurship: Theory, Process, Practise Mason. Ohio; Thomson South Western.

Kurniawan, B., \& Gunawan, N. M. (2019). Utilization of Technology in Online Business College. IOP Conference Series: Materials Science and Engineering, 662.

Leung, Y. K., Franken, I. H. A., \& Thurik, A. R. (2020). Psychiatric Symptoms and Entrepreneurial Intention: The Role of the Behavioral Activation System. Journal of Business Venturing Insights. Vol. 13, 1-10.

Li, L., \& Wu, X. (2017). Number of Siblings, Credit Constraints and Entrepreneurship. The Journal of Development Studies. 54 (7).

Lichtenstein, G. A., \& Lyons, T. S. (2001). The Entrepreneurial Development System: Transforming Business Talent and Community Economies. Economic Development Quarterly. Vol. 15, 3-20.

Lind, P. (2005). Competitiveness through Increased Added Value: A Challenge for Developing Countries. Journal Comparative International Management. Vol 8 (1).

Lindquist, M. J., Sol, J., Van Praag, M., \& Vladasel, T. (2016). Family Background and Entrepreneurship. The DRUID 20 th Anniversary Conference 2016, Denmark.

Lo, C., Sun, H., \& Law. K. (2012). Comparing the Entrepreneurial Intention between Female and Male Engineering Students. Journal of Women's Entrepreneurship and Education. $1(2), 28-51$.

Lussier, R. N. (2008). Human Relation in Organization: Application and Skill Building. New York; McGraw Hill. 
Lyons, T. S., Lyons, J. S. \& Jolley, G. J. (2019). The Readiness Inventory for Successful Entrepreneurship (RISE): A Tool for University Engagement in Entrepreneurial Learning. The Journal of Economic Development in Higher Education. Vol. 2, 1-7.

Mahashim, B. (1985). Pengurusan Perniagaan: Panduan Asas. Petaling Jaya; Fajar Bakti. Marniati. (2016). Entrepreneurship Motivation of Vocational High School Student. Proceedings of the International Mechanical Engineering and Engineering Education Conferences (IMEEEC 2016), AIP Conference Proceeding 1778.

Marshall, A. (2009). Principles of Economics: Unabridged Eighth Edition. Cosimo; Inc. Mazzarol. (2011). Entrepreneurship and Innovation. Edisi ke-2. Australia: Tilde University Press.

McMillan, J., \& Woodruff, C. (2002). The Central Role of Entrepreneurs in Transition Economies. Journal of Economic Perspectives. 16 (3), 153-170.

Mustafa, M. B. (2019). Factors Stimulating Students to Venture into the Field of Entrepreneurship towards Producing Entrepreneurs among University Students. International of Academic Research in Business and Social Sciences, 9 (3), 875-883.

Mustapha, Z., Atan, N. A., \& Ridzwan, E. M. (2017). Lonjakan Nilai-Nilai Keusahawanan Pelajar Politeknik menerusi Program i-SMART. Advanced Journal of Technical and Vocational Education. 1 (1), 291-300.

Nagarathanam, R., \& Buang, N. A. (2015). Potensi dan Peningkatan Kejayaan Usahawan Wanita di Malaysia. Kolokium Penyelidikan Pendidikan Kebangsaan, organized by Politeknik METrO Johor Bahru, 3.

Norain, D. (2015). Factors Influence Women Entrepreneur Business Success. Sintok, Kedah; Universiti Utara Malaysia.

Norasmah, O., \& Faridah, K. (2010). Entrepreneurship Behaviour amongst Malaysia University Students. Pertanika Journal Social Science \& Humanities. 18 (1). 23-32.

Omolara, E. A. (2018). Entrepreneurial Skills and Growth of Small and Medium Enterprise (SMEs): A Comparative Analysis of Nigerian Entrepreneurs and Minority Entrepreneurs in the UK. MPRA Paper, No. 86751.

Pauceanu, A. M., Alpenidze, O., Edu, T., \& Zaharia, R. M. (2019). What Determinants Influence Students to Start their Own Business? Empirical Evidence from United Arab Emirates Universities. Sustainability, 11 (92), 1-23.

Peng, Q., \& Yan, M. (2010). The Research on Entrepreneurship of College-Students in China. UMEA University; China.

Podsakoff, P. M., MacKenzie, S. B., Lee, J., \& Podskaoff, N. P. (2003). Common Method Biases in Behavioral Research: A Critical Review of the Literature and Recommended Remedies. Journal of Applied Psychology, 88 (5), 879-903.

Podsakoff, P. M., Mackenzie, S. B., \& Podskaoff, N. P. (2012). Sources of Method Bias in Social Science Research and Recommendations on How to Control It. Annual Review of Psychology. 63, 539-569

Rengamani, J., \& Ramachandran, S. (2015). A Study on the Entrepreneurial Skills among Students in Chennai. International Journal of Advanced Research in Management. Vol. 6 (3), 36-44

Schwarzl, S., \& Grabowska, M. (2015). Online Marketing Strategies: The Future is Here. Journal of International Studies. 8 (2), 187-196.

Sharif, S. (2019). Statistics for NonStatisticians: Basic Guide to SPSS. Khazanah Darulaman: Malaysia

Shen, T., Osorio, A. E., \& Settles, A. (2017). Does Family Support Matter? The Influence of 
Support Factors on Entrepreneurial Attitudes and Intentions of College Students. Academy of Entrepreneurship Journal. Vol 23 (1), 24-43.

Solek-Borowska, C., \& Chudy-Laskowska, K. (2017). Through the Gender Looking Glass: Female Students Attitude Towards Entrepreneurship. Modern Management Review. 22 (24), 91-208.

Sorensen, J. B. (2007). Closure and Exposure: Mechanisms in the Intergenerational Transmission of Self-employment. Research in the Sociology of Organizations. 25, 83 124.

Steven, S. (2009). 13 principles of Effective Time Management for Freelancer. http://www.designm.ag/freelance/principles.tim.

Sunday, O. C., Olakunle, O. P., \& Itodo, C. I. (2019). Entrepreneurship and Effective Time Management: A Route to Successful Venture. Islamic University Multidisciplinary Journal. Vol. 6 (2), 133-138.

Tawil, N. M., Hassan, R., Ramlee, S., \& K-Batcha, Z. (2015). Enhancing Entrepreneurship Skill among University's Students by Online Business Simulation. Journal of Engineering Science and Technology. Special Issue, 71-80.

Tong, X. F., Tong, D. Y. K., \& Loy, L. C. (2011). Factor Influencing Entrepreneurial Intentions among University Students. International Journal of Social Sciences and Humanities Studies. Vol. 3 (1), 487-496.

You, Y., Zhu, F., \& Ding, X. (2017). College Student Entrepreneurship in China: Results from a National Survey of Directors of Career Services in Chinese Higher Education Institutions. Current Issues in Comparative Education, 19 (2), 64-83.

Yulita, Muhamad, S., Rashid, N. K. A., Hussain, N. E., Akhir, N. H. M., \& Ahmat, N. (2020). Resilience as a Moderator of Government and Family Support in Explaining Entrepreneurial Interest and Readiness among Single Mothers. Journal of Business Venturing Insights. Vol. 13, 1-10.

Zahra, S., \& Dess, G. (2001). Entrepreneurship as a Field of Research: Encouraging Dialogue and Debate. Academy of Management Review. 26 (1), 8-11.

Zaimah, R., \& Abdulllah, S. (2017). Tahap Keupayaan Usahawan dalam Perusahaan Kecil dan Sederhana di Kuala Terengganu. Malaysia Journal of Society and Space. 13 (4), 117125.

Zarbakhsh, M., Pourhassani, S. A., Rahmani. M., Rad, M. M., \& Poor, E. K. (2015). The Relationship between Time Management, Self-Eficacy and Entrepreneurship Students. European Online Journal of Natural and Social Sciences. 4 (1), 211-218.

Zolkefli, M. N., Hussain, N. E., \& Chau, D. N. (2019). Faktor yang Mempengaruhi Kejayaan Usahawan di Terengganu. International Journal of Muamalat. 3 (1), 14-25. 